\title{
The Threat of the North Korean Nuclear Program and the Way to Manage It
}

\author{
Xiaoyu Wu \\ Department of International Politics \\ University of Queensland \\ Queensland, Australia \\ E-mail: zk7660@126.com
}

\begin{abstract}
The North Korean nuclear program has long been the focus of the international society and all the parties concerned have been trying every possible means to stop it but in vain. To help people have a clear picture of the North Korean nuclear program and effectively reduce its potential threat, the author first explains reasons for North Korean pursuit for nuclear program and then evaluates the possible effects- direct threat to regional security, indirect support to other nuclear aspirants and open defiance to NPT. Finally, she puts that pure economic sanctions or political disintegration can never work, and that truly felt responsibility from the U.S-led alliance for the security of China and ordinary citizens of North Korea as well as China's active involvement in the sanctions can really count.
\end{abstract}

Keywords -North Korea; nuclear program; reasons; threat; manage

\section{INTRODUCTION}

Since the 1950s, North Korea has been active in its nuclear program after the Korean War and the deployment of American military forces in South Korea. Pyongyang restarted its nuclear program in the 1990s, and after a brief suspension, it has proposed a policy to develop its nuclear program as well as its economy simultaneously. Whether facing the six-party talks, or the sanctions initiated by the international community, North Korea still continues its nuclear program as well as delivery system. It has conducted nuclear tests in 2003, 2006, 2009, 2016 and 2017, and all the attempts from the international community failed to stop Pyongyang from giving up its nuclear program ${ }^{[1]}$. There were about 10 nuclear warheads after the nuclear test in 2016, and North Korea is approximating to the ability to create nuclear weapons ${ }^{[2]}$. Just in recent months, it has launched its missiles and another nuclear test, so its nuclear program and its leading role for other nuclear aspirants are posing a greater and greater threat to the security of the East Asia, the Middle East and international society. Then what are the main reasons for its unclear program and how can international society manage it?

This article argues that the paramount goal of the regime survival is the main reason that North Korea pursues nuclear weapons, and it will not abandon its nuclear program unless it is used as an exchange for its survival. For the international community, it needs to seize the time to adopt more effective measures to resolve the Pyongyang's nuclear issue and to prevent it from causing greater security threats to the world peace and stability. To be specific, in the first part, I attempt to explore the factors that drive Pyongyang to start its nuclear program. Then, I will focus on the threat North Korea poses to the international peace and security. Lastly, I will try to discuss how to manage the North Korean nuclear challenge.

\section{REASONS FOR NORTH KOREA TO ACQUIRE NUCLEAR WEAPONS}

It is argued that there are several reasons for nuclear proliferation. Specifically, a state determines to pursue nuclear weapons due to its "threat perceptions, economic resources and technical capabilities, domestic political structures, strategic considerations, and calculations that could in turn be influenced by external variables"[3]. I think, of these reasons, three main factors drive the DPRK to pursue nuclear weapons: threat perceptions, domestic political structures and strategic considerations. Firstly, when a state perceives threat, nuclear weapons can form nuclear deterrence to potential and actual adversary even if its conventional military capabilities are not sufficient ${ }^{[4]}$. North Korea feels great and real threat from South Korea and its allies and the deployment of THAAD and their endless military exercises are good examples in case. Secondly, under the special domestic political structures, North Korea hopes to maintain its survival with nuclear weapons. That is to say, North Korea regime regards nuclear weapon as the most significant for Kim Jong-il to maintain the legitimacy of his leadership. And its policy makers believe that with nuclear weapons, the regime will gain more prestige in international community. Thirdly, strategic considerations of national defense also attract a state to develop nuclear, and Pyongyang hopes to avoid being invaded by the US with nuclear weapons. Even with only one of the factors, it is difficult to persuade a state to abandon its nuclear program; and thus, with the three factors reinforcing one another, it is almost impossible for Pyongyang to give up its pursuit for nuclear weapons in exchange for security assurances, diplomatic recognition and economic aid, as North Korea never treats its nuclear program as a bargain ${ }^{[5][6]}$. Although the DPRK is the most opaque state with limited communication with the outside world, there is growing evidence showing that its nuclear program is based primarily on the perception of foreign threats as well as the pursuit of 
national security.

From the domestic perspective, the evidence provided by the high-level defectors has proved that Pyongyang believes that the surrounding world is hostile and threatening. For instance, Hwang Jang-yop narrated that North Koreans only worshiped powerful states in their diplomacy and hoped to become powerful ${ }^{[6]}$. And from Hwang, North Koreans regarded nuclear weapons as a way to be powerful due to its devastating capability. Besides, the leaders of the regime believed that only with nuclear weapons, could they defend their regime and survive in the international community.

From the international perspective, both the collapse of the Soviet Union and the perceived threat from the United States drive the DPRK to focus on its nuclear program ${ }^{[7]}$. Pyongyang experienced economic recession in the early 1990s because of its lack of oil and agricultural supplies, which made it largely live on international assistance ${ }^{[8]}$. Meantime, the diplomatic relationship established between North Korea and the Soviet Union set it against the US and the collapse of the Soviet Union worsened its living environment in international society - not only losing its powerful ally, but further isolated by the US. It was the Korean War that first made Pyongyang clearly recognize the great threat posed by America, for America acquired the control over its enemies quickly; and later the US has been the sole superpower in the world after the collapse of the Soviet Union and it is also the dominance of East Asia ${ }^{[9]}$. Therefore, the power of the US and its troops in South Korea make North Korea persistent on the nuclear program to gain the capability of self reliance ${ }^{[10]}$. To be specific, although there is a great gap in conventional military forces between the DPRK and the US, North Korea can make up for this gap through the acquisition of nuclear weapons, which can form nuclear deterrent to the US from invasion. What is more, Pyongyang was recognized as a member of the "axis of evil" by the Bush administration in 2001, which means Pyongyang is identified as a target of nuclear strike ${ }^{[11]}$.

In summary, the primary goal for the regime of North Korea is to survive in the brutal international community with the threat perception from the US. To achieve this goal, North Korea determined to acquire nuclear weapons.

\section{ThreAtS TO INTERNATIONAL PEACE AND SECURITY}

The North Korean nuclear program not only threatens the stability of East Asia, but also encourages the potential proliferants such as Iran to develop nuclear program to some extent, which will greatly influence the nuclear nonproliferation regime.

\section{A. Threat to Regional Stability}

The North Korean nuclear program may not directly lead the major powers in East Asia to develop nuclear weapons, however, it is more likely to deepen the security dilemma among China, the United States, Japan, and South Korea, thus affecting the stability of regional order.
As Japan has expressed the desire to expand military activities in order to acquire the capability of "collective self-defense" due to the nuclear program of North Korea ${ }^{[12]}$, China has shown its concerns for Japan, worrying that the expansion of Japanese military activities do harm to China's national security. And the missile defense system which is deployed in South Korea seems to undermine China's nuclear deterrent, which has triggered China's economic sanctions against South Korea. If the military capabilities of South Korea and Japan are increased, China may choose to increase its nuclear capability to maintain its nuclear deterrent against them. In turn, the US as well as its allies may misperceive the intention of China, interpreting it as challenging the dominance of the US in East Asia. In this case, the allies may choose to increase their military capability, and the US may release hostile signals against China and even bring Taiwan into the arm race. This will form a vicious circle, "mutual suspicion and tension would further grow, and the region would become unstable" ${ }^{\text {[12] }}$. The unstable East Asia is an obstacle to all major powers in the region and they do not intend to have military clashes with each other, because these powers are economically interdependent on each other, cooperated in global anti-terrorism, environment protection and the like.

\section{B. Support to Other Potential Proliferants}

North Korea's efforts to develop nuclear weapons and the corresponding reaction of the international community can provide other countries that are considering developing nuclear weapons with some lessons and suggestions.

First, if the international community does not take more stringent and effective measures, the DPRK may succeed in the completion of nuclear program with only little price; and thus other nuclear aspirants such as Iran will be encouraged to restart their nuclear programs. To be specific, as "Iran has declared its program peaceful”, and if Iran and other potential proliferants claim that they just start their nuclear program to supply domestic energy, it is difficult for international community to take drastic measures to stop their nuclear programs $^{[13]}$. And they can even argue that Pyongyang has not been severely punished for its non-peaceful nuclear program, and that there is no good reason for the international society to severely punish them for their peaceful ones. Moreover, in terms of North Korea, the development of nuclear weapons can not only guarantee the survival of the regime, but also strengthen the domestic political status of the leaders. It is precisely because of the nuclear program that Kim Jong-il can respond to the serious domestic economic crisis while ensuring the legitimacy of his leadership.

Second, if the DPRK can be successful in creating nuclear weapons, it is more likely to provide other non-nuclear states with both commodities of nuclear weapons or technology and technical assistance. North Korea will be willing to sell its nuclear weapons to earn more money because of the strict sanctions from the international society. Even if the US as well as the UN closely monitors Pyongyang's nuclear 
weapons exports to stop its exports, North Korea can also make money through the sale of nuclear weapons technology based on several consumer states including Iran and Egypt. We even have good reasons to believe that North Korea may sell nuclear weapons or nuclear technology to terrorist groups for economic purposes ${ }^{[13]}$. Besides, North Korea can also choose to provide technical assistance or technical aid covertly, as it has already done to Syria and Myanmar.

Besides, the situation in the Middle East may become more complicated under the encouragement of the DPRK if cooperation on nuclear program strengthens between North Korea and $\operatorname{Iran}^{[3]}$. With Iran's intent to restart its nuclear program, Israel may take military measures as a response, and all the neighbor countries, especially Arabian countries, may attempt to prevent Iran from becoming a regional hegemony by developing nuclear weapons. In this case, all potential proliferants will be motivated and the development of nuclear weapons will be promoted.

\section{Challenges to the NPT}

It is known that both India and Pakistan conducted nuclear tests in the 1990s, which has eroded the nonproliferation regime and become a headache of international community. To make things worse, the DPRK became the first country to withdraw from the NPT and conducted nuclear tests, and it has already done more serious damage to the nonproliferation regime $^{[13]}$. If DPRK was not punished for its withdrawal by international community, it means that the NPT is not compulsory; instead, it can be challenged with the disobedience and noncompliance. That is to say, Pyongyang is not only threatening regional stability, but also challenging the NPT.

Second, the ongoing nuclear program of the DPRK also exposes the inherent flaws of NPT - not non-discrimination, having double standards and lacking enforcement. NPT is discriminatory and has double standards, for it is legitimate for some states to have nuclear weapons that are regarded as able to maintain regional stability; while it is illegal for other states to pursue nuclear weapons that are likely to destabilize the region. NPT lacks enforcement because it could not stop Pyongyang's withdrawal from it and imposed no control over Pyongyang.

Third, the DPRK's nuclear program could also lead to a new round of nuclear proliferation: East Asia, the Middle East and even terrorist organizations all have a chance to become new owners of nuclear weapons, which will undermine the efforts of the international community to prevent nuclear proliferation. On the one hand, the other major powers in East Asia may seek to develop nuclear weapons, which will damage the nuclear nonproliferation regime. For instance, if North Korea eventually succeeds in its nuclear program, Japan will be skeptical of the security guarantee provided by the United States, and the US is more likely to focus more on the security of its mainland rather than on Japan if the nuclear weapons produced by Pyongyang are able to reach America. Therefore, Japan may consider developing nuclear weapons for its self-defense purposes. However, there is nuclear taboo that is widely accepted in Japan of "not possessing, producing, or allowing nuclear weapons", as it was once the victim of the atomic bomb ${ }^{[12]}$. So, if Japan decides to start nuclear program, it will seriously undermine the nuclear nonproliferation regime not only because it is a significant sponsor of the NPT, but also because it is a victim and is one of the countries that have the strongest desire to stop nuclear proliferation. On the other hand, the spread of nuclear weapons or technology from Pyongyang to other places will also erode both the export control system and the regime itself. If states in the Middle East purchase or get assistance from North Korea, it implies that the control over nuclear exports is ineffective, and the Middle East will be more unstable. More seriously, if nuclear weapons or technology are acquired by terrorists, there will be more battles and more civilians will be harmed.

\section{Ways to Manage The North Korean NuClear CHALLENGE}

\section{A. Mainly by Sanctions while Other Means as a Supplement}

The Obama administration adopted the policy "strategic patience" against the DPRK, which means "the United States would not move first until North Korea displays a sincere effort to denuclearize and come back to the negotiation table"[14]. With this policy, the US intends to achieve the goal of North Korean denuclearization by arms interdictions and economic sanctions and hopes to convince China to cooperate on this issue. However, this policy does not solve practical problems; instead, it gives Pyongyang time and space to improve its military capability.

Hence, to achieve the goal of denuclearization, an unrelenting and intensive financial isolation is desperately needed. First, some specific contents of sanctions need to be strengthened in order to threaten the survival of the DPRK. To be specific, it is necessary to monitor the arms trade and restrict the court economy, because the two kinds of income only aim at supporting the survival of the regimes rather than supporting the lives of ordinary North Koreans ${ }^{[15]}$. Second, it is also significant for the American banks to monitor the offshore assets of Pyongyang and target the shadow economy ${ }^{[16]}$. But the sanctions need to be smart in order to provide the ordinary North Koreans with food and medicine. Third, the US needs to take measures to prevent companies or banks from assisting North Korea covertly such as sanctioning some banks of China.

And there are also some other means supplemented to help to achieve the goal. First, political subversion is a good way to disintegrate the DPRK. Specifically, the US can be committed to facilitating the high-level mutiny in Pyongyang, and attempts to attract the political elites of North Korea with a more free and democratic political environment. For example, the betrayed North Korean diplomats "exposed large parts of Pyongyang's money-laundering network” in $2016^{[16]}$. Second, the defense system against Pyongyang is also essential. The missile defense system has been deployed in both South Korea and the US, and the defense system against 
conventional weapons is also indispensable. It is argued that North Korea is more likely to attack South Korea unless it can "anticipate military success against the ROK army and US forces in Korea” by defeating South Korea through a blitzkrieg $^{[12]}$. And if Pyongyang uses nuclear weapons to launch an attack, its own military advance will be slowed down due to the debris, electromagnetic pulse and radiation produced by nuclear explosion. Therefore, the US is required to strengthen both nuclear deterrence and conventional deterrence. Third, whatever means the international community chooses, "maintaining a strong coalition among concerned parties to ensure the effectiveness of these strategies" is also important ${ }^{[17][18]}$.

\section{B. How to Persuade China to Enforce Sanctions}

It is argued that effectiveness and enforcement of the sanctions against the DPRK largely depends on China's attitude and acts. However, China has good reasons to adopt "two-pronged North Korea policy" by opposing North Korea to develop weapons programs while propping up its economy: China does not expect North Korea to acquire nuclear weapons as it will pose threats to China; and China does not want North Korea to be involved in a war or to collapse, for it will also threaten China ${ }^{[19][13]}$.

On the one hand, North Korean nuclear program threatens China. First, if Pyongyang acquires nuclear weapons, there will be ripple effect in the region implying that Japan, South Korea, and even Taiwan will pursue closer military cooperation with the US to seek the security guarantee under nuclear umbrella, which will strengthen their alliances with the US. They may even intend to start nuclear programs. Second, Beijing also concerns that the US may resort to military intervention such as preemptive strikes against North Korea to require the DPRK to denuclearize. And if Pyongyang responds with the attack on South Korea, a war will break out near China's border. The war will pose a great threat to China, not only because the American armies are close to China's border. A war on Korean Peninsula, or the collapse of the DPRK, will also bring a large number of refugees to China. Out of humanitarianism, China cannot repatriate them to North Korea, but accepting them implies a significant pressure on border areas with higher unemployment rates ${ }^{[19]}$. More importantly, the war will bring great trouble to Chinese economy, for the major trade partners of China will be involved in the war. Third, the way China chooses to deal with the North Korean nuclear issues will influence both the image of China and the relationship with the international society. In other words, China's image of becoming a responsible rising power will be damaged if it is not actively involved in the settlement of the issue; Beijing will face the threats mentioned above if it strictly imposes sanctions against Pyongyang.

On the other hand, the collapse of North Korea also threatens China. A unified Korea implies China's border will be directly adjacent to the US troops, which worries Beijing $^{[13]}$. Also, a new Pyongyang regime or a reunified
Korea is likely to seek funding from China ${ }^{[19]}$, and China is likely to spend a large amount of money maintaining the stability of the border between China and North Korea as well as supporting the lives of refugees.

Therefore, Beijing can not be encouraged to enforce its sanctions against Pyongyang unless it feels that the threat posed by the DPRK's nuclear weapons exceeds that posed by the collapse of the regime. That is to say, the US can sign peace treaties with China, promising to withdraw the THAAD from South Korea, reduce the troops stationed in South Korea and keep no troops or any other missile defense system in the Sino-Korean border after the denuclearization of North Korea. Besides, the US and South Korea have to make sure that they will also be responsible for the poor people and the development of North Korea.

\section{CONCLUSION}

The North Korean has launched missiles and nuclear tests every now and then, which not only takes the lead among nuclear aspirants, but poses a greater threat to the security of the East Asia, the Middle East and the international society. All parties concerned have taken measures like sanctions, embargoes and diplomatic isolation, but there have come no effective results. Hence, besides China's active involvement, it is better for the US-led alliance to first give up their frequent joint drills; the US to actively reduce or even withdraw its troops from the Asian-Pacific region; and Japan and South Korea to make China and North Korea really feel the sincerity of their promises or acts and therefore willing to cooperate with the international society.

\section{REFERENCES}

[1] S.D. Sagan, "Policy: a call for global nuclear disarmament," Nature, vol. 487(7405), pp. 30-32. 2012.

[2] J.S. Wit, and Young-Ahn. Sun, "North Korea's nuclear futures: technology and strategy,” US-Korea Institute at SAIS, 2015.

[3] Jing-Dong. Yuan, "DPRK Nuclear challenges and the politics of nonproliferation,” in North Korean Nuclear Operationality Regional Security and Nonproliferation, edited by G.J. Moore, and G. Allison, Baltimore: Johns Hopkins University Press. pp. 218-236. 2014.

[4] S.D. Sagan, "Why do states build nuclear weapons? Three models in search of a bomb,” International Security, vol. 21(3), pp. 54-86. 1996.

[5] B. Habib, and A. O’Neil, "North Korea's emergence as a nuclear weapons state and the end of the disarmament paradigm," Global Change, Peace \& Security, vol. 21(3), pp. 377-387. 2009.

[6] A. O’Neil, “Learning to live with uncertainty: the strategic implications of North Korea's nuclear weapons capability," Contemporary Security Policy, vol. 26(2), pp. 317-334. 2005.

[7] W.C. Clemens, "North Korea's quest for nuclear weapons: new historical evidence," Journal of East Asian Studies, vol. 10(1), pp. 127-154. 2010.

[8] M.B. Nikitin, "North Korea's nuclear weapons: technical issues," Current Politics and Economics of Northern and Western Asia, vol. 21(2), pp. 181-220. 2012.

[9] M.D. Cohen, "North Korea, nuclear weapons, and no good options? A controlled path to peace,” Asian Journal of Peacebuilding, vol. 1(2), pp. 179-195. 2013.

[10] N.D. Anderson, "Explaining North Korea's nuclear ambitions: power and position on the Korean Peninsula," Australian Journal of 
International Affairs, vol. 71(6), pp. 621-641. 2017.

[11] M.J. Hanson, "Nuclear weapons as obstacles to international security," International Relations, vol. 16(3), pp. 95-105. 2002.

[12] Dong-Sun. Lee, “A nuclear North Korea and the stability of East Asia: a tsunami on the horizon?,” Australian Journal of International Affairs, vol. 61(4), pp. 436-454. 2007.

[13] M.R. Rublee, "Global consequences of an operationally nuclear North Korea,” in North Korean Nuclear Operationality Regional Security and Nonproliferation, edited by G.J. Moore, and G. Allison, Baltimore: Johns Hopkins University Press. pp. 201-217. 2014.

[14] D. Kim, “The Obama administration's policy toward North Korea: the causes and consequences of strategic patience,” Journal of Asian Public Policy, vol. 9 (1), pp. 32-44. 2016.

[15] M. Weissmann, and L. Hagström, "Sanctions reconsidered: the path forward with North Korea,” The Washington Quarterly, vol. 39(3), pp. 61-76. 2016.

[16] J. Stanton, Sun-Yoon Lee, and B. Klingner, "Getting tough on North Korea: how to hit Pyongyang where it hurts," Foreign Affairs, vol. 96(3), pp. 65-75. 2017.

[17] C. Kang, "The North Korean nuclear problem: twenty years of crisis," Asia Policy, vol.19(1), pp. 28-36. 2015.

[18] V. Jackson, "Deterring a nuclear-armed adversary in a contested regional order: the 'trilemma' of U.S.-North Korea relations,” Asia Policy, (23), pp. 97-103. 2017.

[19] G.J. Moore, "Beijing's problem with an operationally nuclear North Korea," in North Korean Nuclear Operationality Regional Security and Nonproliferation, edited by G.J. Moore, and G. Allison, Baltimore: Johns Hopkins University Press. pp. 77-103. 2014. 